\title{
Study of the Effect of Silymarin on Viability of Breast Cancer Cell Lines
}

\author{
Saieh Hajighasemlou1,2, Mohammadmorad Farajollahi2,3*, Mahmoud Alebouyeh1, \\ Hossein Rastegar ${ }^{1}$, Mojgan Taghizadeh Manzari', Milad Mirmoghtadaei ${ }^{4}$, Behjat Moayedi ${ }^{5}$, \\ Maryam Ahmadzadeh ${ }^{6}$, Mansure Kazemi ${ }^{7}$, Farzad Parvizpour ${ }^{8}$, Safoora Gharibzadeh ${ }^{9}$ \\ ${ }^{1}$ Iran Foods and Drug Organization, Tehran, Iran \\ ${ }^{2}$ Department of Biotechnology, Iran University of Medical Sciences, Tehran, Iran \\ ${ }^{3}$ Alborz Food and Drug Laboratory, Fardis, Iran \\ ${ }^{4}$ School of Medicine, Tehran University of Medical Sciences, International Campus (TUMS-IC), Tehran, Iran \\ ${ }^{5}$ Isfahan University of Medical Sciences, Isfahan, Iran \\ ${ }^{6}$ Department of Pharmaceutical Biotechnology, School of Pharmacy, Shahid Beheshti University of Medical \\ Sciences, Tehran, Iran \\ ${ }^{7}$ Department of Tissue Engineering, School of Medical Advanced of Technologies in Medicine, Tehran \\ University of Medical Sciences, Tehran, Iran \\ ${ }^{8}$ Department of Applied Cell Sciences, School of Medical Advanced of Technologies in Medicine, Tehran \\ University of Medical Sciences, Tehran, Iran \\ ${ }^{9}$ Department of Epidemiology and Biostatistics, School of Public Health, Tehran University of Medical Sciences, \\ Tehran, Iran. \\ Email: $\underline{\text { mahdiy@yahoo.com }}$
}

Received 1 May 2014; revised 1 June 2014; accepted 28 June 2014

Copyright (C) 2014 by authors and Scientific Research Publishing Inc.

This work is licensed under the Creative Commons Attribution International License (CC BY).

http://creativecommons.org/licenses/by/4.0/

(c) (7) Open Access

\section{Abstract}

Background: Breast cancer is the most prevalent cancer and results in $14 \%$ of cancer-related deaths among women worldwide. The aim of this study is to investigate the anticancer effects of Silymarin on two breast cancer cell lines (BT-474, SK-BR-3). Methods and Material: Two breast cancer cell lines-SK-BR-3 and BT-474-were incubated for 24 hours in standard conditions before adding 100, 200, 400, 800, $1600 \mu \mathrm{M}$ Silymarin to each well. Alamar blue was then added to the wells after 24, 48 and 72 hours of incubation and cell viability was determined using fluorescence reader to detect the optical density. Results were analyzed using generalized estimating equations (GEE) method in STATA 12.0. Results: we demonstrated the Silybum marianum inhibition of two-cell lines SK-BR-3 and BT-474 growth at different concentrations after 24, 48 and 72 hours. Silymarin increased cell death in both cell lines. Conclusion: Silymarin can be combined with other anti-neoplastic agents to obtain better results.

*Corresponding author. 


\section{Keywords}

\section{Silymarin, Breast Cancer, SK-BR-3, BT-474}

\section{Introduction}

Silybum marianum (milk thistle) is a plant of the Asteraceae family that grows naturally in some parts of Europe, Asia (including Iran) and the United States [1]. Silymarin is a complex mixture of polyphenolic molecules, including seven closely related flavonolignans (silybin A, silybin B, isosilybin A, isosilybin B, silychristin, isosilychristin, silydianin) and one flavonoid (taxifolin); the active ingredient is Silibinin which has long been used in traditional medicine and shows antioxidant, anti-inflammatory and anti-cancer properties and can induce apoptosis in some cells [2] [3]. Anti-neoplastic properties of Silymarin have been demonstrated in cancers of prostate [4]-[6], Ovaries, lung, skin, bladder and breast [7]-[11].

Although the exact mechanisms involved in antineoplastic effects of silymarin in breast cancer have not been identified, possible underlying explanations include induction of G1 arrest and apoptosis through inhibiting cyclin-dependent kinases activity and epidermal growth factor receptor signaling, and increasing Cip1/p21 and p27 [9] [12]-[16].

Breast cancer is a major health problem more commonly seen in the developed countries. Breast cancer is the leading cause of death in women 40 - 59 years and more than a million new cases are detected annually [17] [18]. In Iran breast cancer is the commonest cancer among women comprising $21.4 \%$ of all cancers among females. Studies indicate that breast cancer presents about one decade earlier in Iranian women than in developed countries [19]-[21].

In present study, we examine the in vitro effect of different Silymarin concentrations on two breast cancer cell lines: SK-BR-3 and BT-474 by determining cell viability after 24, 48 and 72 hours of incubation with alamar blue using fluorescent reader.

\section{Materials and Methods}

Silymarin powder (Sigma) solution in Dimethyl Sulfoxide (DMSO, Sigma) was prepared as stock at the concentration of $30,000 \mu \mathrm{L} / \mathrm{mL}$ and kept at $-20^{\circ} \mathrm{C}$. During the test required concentrations using phosphate buffered saline (PBS) were prepared from this stock solution. Cell culture medium (Gibcoß) consisted of RPMI1640 and DMEM, trypsin, antibiotics, fresh bovine serum (FBS) and anti-mycoplasma. Alamar blue fluorescence reagent from Invitrogen and cell lines SK-BR-3 and BT-474 were purchased from Cell Bank of Iran, Pasteur Institute. Cells were cultured at standard conditions (temperature of $37^{\circ} \mathrm{C}$, humidity of $95 \%$ and $5 \% \mathrm{CO}_{2}$ gas pressure) and the culture was replaced at 48 and 72-hour intervals.

A suspension of 25,000 cells were added to each well and incubated for 24 hours at $37^{\circ} \mathrm{C}$ to stick to the bottom of the wells. 10 wells were assigned for each concentration (100, 200, and 400, 800 and $1600 \mathrm{mM})$ and 10 wells without Silymarin as our controls. The DMSO concentration in the controls wells was adjusted to be the same as the test wells.

After incubation the wells for 24, 48 and 72 hours, $25 \mu$ Alamar blue was added to each well and the plates were incubated for an additional 3 hours. Absorbance was measured at 530 and $590 \mathrm{~nm}$ using a fluorescence reader.

\section{Results}

Results of the effect of Silybum marianum were evaluated on two cell lines BT-474 and SK-BR-3 are summarized in the Figure 1 and Figure 2.

Time trends of cells were examined using generalized estimating equations (GEE) that account for correlation between samples. For BT-474 cell line we found significant difference between samples of different incubation periods (P-value $<0.001$ ). We then compared the control group with different silymarin concentrations of different incubation periods (one to three days). Table 1 shows the significance difference between the control and silymarin groups. This difference remains significant but declines after Day 1. 


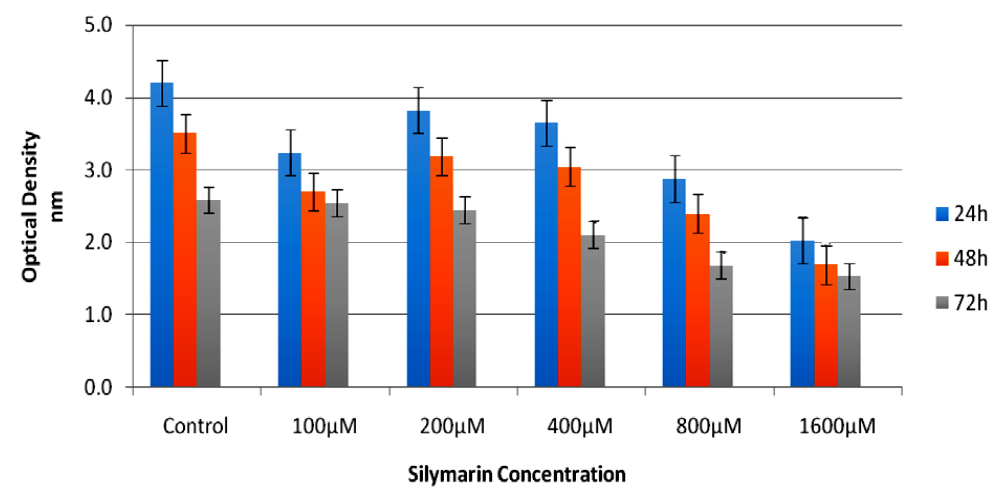

Figure 1. Silymarin effect on the BT-474 cell line after 24, 48 and 72 hours of incubation: Cell viability was significantly reduced compared to control for all concentrations at 24 and 48 hours and for concentrations of $\geq 400 \mu \mathrm{M}$ at 72 hours.

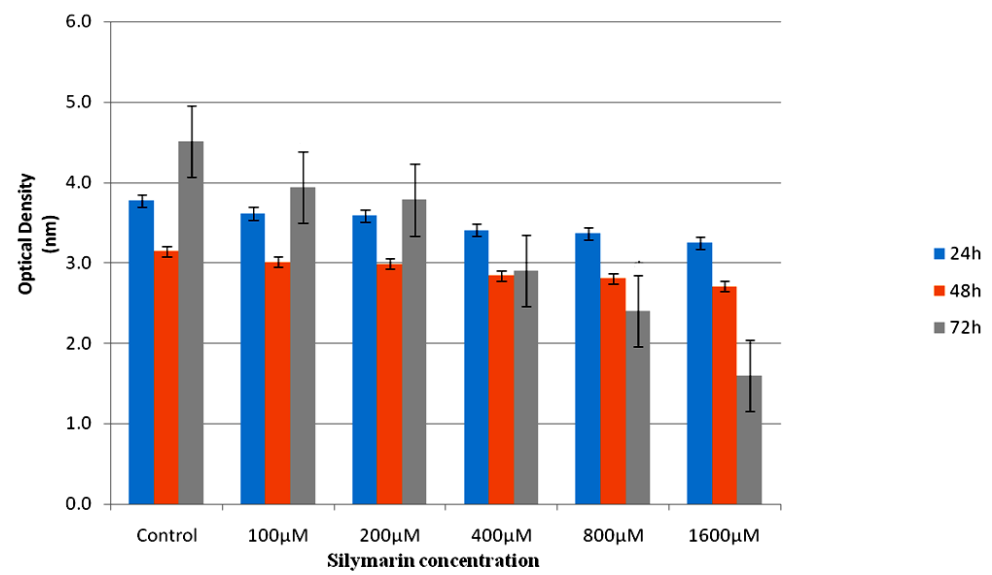

Figure 2. The effect of Silymarin on the SK-BR-3 cell line after 24, 48 and 72 hours: Cell viability differed significantly at all concentrations only after 72 hours; the difference was not significant at any concentration after 24 or 48 hours of incubation.

Table 1. Comparisons of different concentrations with control group.

\begin{tabular}{ccccc}
\hline & \multicolumn{3}{c}{ BT-474 } & P-value \\
\hline $100 \mu \mathrm{M}$ & Day 1 & Day 2 & Day 3 & $<0.001$ \\
$200 \mu \mathrm{M}$ & -966.72 & -805.6 & -47.8 & $<0.001$ \\
$400 \mu \mathrm{M}$ & -380.88 & -317.4 & -143.3 & $<0.001$ \\
$800 \mu \mathrm{M}$ & -551.64 & -459.7 & -478.9 & $<0.001$ \\
$1600 \mu \mathrm{M}$ & -1326.72 & -1105.6 & -905 & $<0.001$ \\
\hline
\end{tabular}

For SK-BR-3 cell line we also found a significant interaction between incubation period (days) and different concentrations, which suggests a varying degree of silymarin effect at the same concentration but in different incubation periods; we could not however detect any pattern for such decline.

\section{Discussion}

Anti-growth and anti-tumor effects of Silybum marianum have been noted in many cancers over recent years. This study was the first to employ Alamar blue in order to detect cell viability which is more sensitive than the 
conventional MTT assay [22].

In the present study, cell viability was significantly reduced in comparison to the controls. This effect increased over the time course from 24 - 72 hours, and also from lower to higher concentrations of Silymarin from 0 - $1600 \mu \mathrm{M}$. Our data are in consistent with that of Gharagozloo and colleagues showed that Silybum marianum has an inhibitory effect on HepG2 cell line growth [23]. It would be compatible with the research by Singh who has studied the effect of Silybum marianum on human endothelial cell line and has showed that this drug is able to inhibit cell proliferation [24], also compatible with the research by Li and colleagues that examined the effect of Silybum marianum on cell Anip973 line (lung cancer), and showed that Silybum marianum inhibited cell proliferation and activates apoptosis via the mitochondrial pathway [25]. Sigh and colleagues in other study, the effect of Silybum marianum on Hairless SKH-1 mice, demonstrated that it has a strong protective effect against photocarcinogen and inhibitory effects on inflammatory responses and angiogenesis [26]. Similarly, Rajamanickam and colleagues examined the effect of Silybum marianum on colorectal cancer in a mouse model of APC $(\mathrm{min} /+)$ and showed that it had anticancer effects in this model of cancer that is consistent with the findings from this study [27]. The results would be compatible with the results of the study by Kim and colleagues in 2011, showed that Silymarin could reduce the ligand-induced EGFR and metalloproteinase 9 (MMP-9) in both cell lines SK-BR-3 and BT-474 [28]. Our results are compatible with research by Provinciali that showed antitumor effects of the silybin-phosphatidylcholine complex (IdB 1016) on the development of mammary tumors in HER-2/neu transgenic mice [29].

Here we suggest that a similar mechanism is involved as has been proposed for silymarin effect on prostate cancer: G1 phase cell cycle arrest most probably through inhibition of cyclin-dependent kinases (CDK) activity and epidermal growth factor receptor (erbB2) signaling [9] [12]-[14].

As showed above in vitro and in vivo studies and the results of the present study, all confirmed antioxidant and anticancer properties of these drugs. The highest concentration of Silymarin used in this study was the 1600 $\mu \mathrm{M}$; higher doses are suggested to achieve the optimum dose. The highest level of cell apoptosis observed in the present study at 72-hour incubation proposed that long-term incubation of cells with the drug may increase efficiency of its action on the cancer cells. Both cell lines studied here were Her2 positive, a similar study on Her2 negative cell lines would be valuable.

\section{Conclusion}

We demonstrated the Silybum marianum inhibition of two cell lines SK-BR-3 and BT-474 growth at different concentrations, and increased cell death in both cell lines. Silymarin can be combined with other anti-neoplastic agents to obtain better results.

\section{Acknowledgements}

We would like to thank all our study participants for their commitment to this study. Iran University of Medical Science and Iran Food and Drug Organization (IRI.FDO) provided financial support.

\section{Conflict of Interest}

This research sponsored by Iran Food and Drug Organization and Iran University of Medical Sciences.

\section{References}

[1] Osuchowski, M., Johnson, V., He, Q. and Sharma, R. (2004) Alterations in Regional Brain Neurotransmitters by Silymarin, a Natural Antioxidant Flavonoid Mixture, in BALB/c Mice. Pharmaceutical Biology, 42, 384-389. http://dx.doi.org/10.1080/13880200490519712

[2] Kroll, D.J., Shaw, H.S. and Oberlies, N.H. (2007) Milk Thistle Nomenclature: Why It Matters in Cancer Research and Pharmacokinetic Studies. Integrative Cancer Therapies, 6, 110-119. http://dx.doi.org/10.1177/1534735407301825

[3] Davis-Searles, P.R., et al. (2005) Milk Thistle and Prostate Cancer: Differential Effects of Pure Flavonolignans from Silybum marianum on Antiproliferative end Points in Human Prostate Carcinoma Cells. Cancer Research, 65, 44484457. http://dx.doi.org/10.1158/0008-5472.CAN-04-4662

[4] Kiruthiga, P.V., Beema Shafreen, R., Karutha Pandian, S. and Pandima Devi, K. (2007) Silymarin Protection against Major Reactive Oxygen Species Released by Environmental Toxins: Exogenous H2O2 Exposure in Erythrocytes. Ba- 
sic Clinical Pharmacology Toxicology, 100, 414-419. http://dx.doi.org/10.1111/j.1742-7843.2007.00069.x

[5] Manna, S.K., Mukhopadhyay, A., Van, N.T. and Aggarwal, B.B. (1999) Silymarin Suppresses TNF-Induced Activation of NF-Kappa B, c-Jun N-terminal Kinase, and Apoptosis. Journal of Immunology, 163, 6800-6809.

[6] Li, L.H., et al. (2007) Silymarin Enhanced Cytotoxic Effect of Anti-Fas Agonistic Antibody CH11 on A375-S2 Cells. Journal of Asian Natural Products Research, 9, 593-602. http://dx.doi.org/10.1080/10286020600882502

[7] Singh, R.P. and Agarwal, R. (2006) Prostate Cancer Chemoprevention by Silibinin: Bench to Bedside. Molecular Carcinogenesis, 45, 436-442. http://dx.doi.org/10.1002/mc.20223

[8] Singh, R.P. and Agarwal, R. (2004) A Cancer Chemopreventive Agent Silibinin, Targets Mitogenic and Survival Signaling in Prostate Cancer. Mutation Research, 555, 21-32. http://dx.doi.org/10.1016/j.mrfmmm.2004.05.017

[9] Zi, X., Grasso, A.W., Kung, H.J. and Agarwal, R. (1998) A Flavonoid Antioxidant, Silymarin, Inhibits Activation of erbB1 Signaling and Induces Cyclin-Dependent Kinase Inhibitors, G1 Arrest, and Anticarcinogenic Effects in Human Prostate Carcinoma DU145 Cells. Cancer Research, 58, 1920-1929.

[10] Scambia, G., et al. (1996) Antiproliferative Effect of Silybin on Gynaecological Malignancies: Synergism with Cisplatin and Doxorubicin. European Journal of Cancer, 32A, 877-882. http://dx.doi.org/10.1016/0959-8049(96)00011-1

[11] Sharma, G., Singh, R.P., Chan, D.C. and Agarwal, R. (2003) Silibinin Induces Growth Inhibition and Apoptotic Cell Death in Human Lung Carcinoma Cells. Anticancer Research, 23, 2649-2655.

[12] Zi, X., Feyes, D.K. and Agarwal, R. (1998) Anticarcinogenic Effect of a Flavonoid Antioxidant, Silymarin, in Human Breast Cancer Cells MDA-MB 468: Induction of G1 Arrest through an Increase in Cip1/p21 Concomitant with a Decrease in Kinase Activity of Cyclin-Dependent Kinases and Associated Cyclins. Clinical Cancer Research, 4, 10551064.

[13] Deep, G., Oberlies, N.H., Kroll, D.J. and Agarwal, R. (2007) Isosilybin B and Isosilybin A Inhibit Growth, Induce G1 Arrest and Cause Apoptosis in Human Prostate Cancer LNCaP and 22Rv1 Cells. Carcinogenesis, 28, 1533-1542. http://dx.doi.org/10.1093/carcin/bgm069

[14] Roy, S., Kaur, M., Agarwal, C., Tecklenburg, M., Sclafani, R.A. and Agarwal, R. (2007) p21 and p27 Induction by Silibinin Is Essential for Its Cell Cycle Arrest Effect in Prostate Carcinoma Cells. Molecular Cancer Therapeutics, 6, 2696-2707.

[15] Kaur, M., et al. (2009) Silibinin Suppresses Growth and Induces Apoptotic Death of Human Colorectal Carcinoma LoVo Cells in culture and Tumor Xenograft. Molecular Cancer Therapeutics, 8, 2366-2374. http://dx.doi.org/10.1158/1535-7163.MCT-09-0304

[16] Zhu, W., Zhang, J.S. and Young, C.Y. (2001) Silymarin Inhibits Function of the Androgen Receptor by Reducing Nuclear Localization of the Receptor in the Human Prostate Cancer Cell Line LNCaP. Carcinogenesis, 22, 1399-1403. http://dx.doi.org/10.1093/carcin/22.9.1399

[17] Jemal, A., et al. (2011) Global Cancer Statistics. CA: A Cancer Journal for Clinicians, 61, 69-90. http://dx.doi.org/10.3322/caac.20107

[18] Ferlay, J., Soerjomataram, I., Ervik, M., Dikshit, R., Eser, S., Mathers, C., Rebelo, M., Parkin, D.M., Forman, D. and Bray, F. (2013) GLOBOCAN 2012 v1.0, Cancer Incidence and Mortality Worldwide: IARC Cancer Base No. 11 [Internet]. Lyon, France: International Agency for Research on Cancer. http://globocan.iarc.fr

[19] Mousavi, S.M., et al. (2007) Breast Cancer in Iran: An Epidemiological Review. The Breast Journal, 13, $383-391$. http://dx.doi.org/10.1111/j.1524-4741.2007.00446.x

[20] Noroozi, A., Jomand, T. and Tahmasebi, R. (2011) Determinants of Breast Self-Examination Performance among Iranian Women: An Application of the Health Belief Model. Journal of Cancer Education, 26, 365-374. http://dx.doi.org/10.1007/s13187-010-0158-y

[21] Bidgoli, S.A., Ahmadi, R. and Zavarhei, M.D. (2010) Role of Hormonal and Environmental Factors on Early Incidence of Breast Cancer in Iran. Science of the Total Environment, 408, 4056-4061. http://dx.doi.org/10.1016/j.scitotenv.2010.05.018

[22] Deep, G. and Agarwal, R. (2007) Chemopreventive Efficacy of Silymarin in Skin and Prostate Cancer. Integrative Cancer Therapies, 6, 130-145. http://dx.doi.org/10.1177/1534735407301441

[23] Gharagozloo, M. and Amirghofran, Z. (2007) Effects of Silymarin on the Spontaneous Proliferation and Cell Cycle of Human Peripheral Blood Leukemia T Cells. Journal of Cancer Research and Clinical Oncology, 133, 525-532. http://dx.doi.org/10.1007/s00432-007-0197-x

[24] Singh, R.P., et al. (2005) Silibinin Strongly Inhibits Growth and Survival of Human Endothelial Cells via Cell Cycle Arrest and Downregulation of Survivin, Akt and NF-kappaB: Implications for Angioprevention and Antiangiogenic Therapy. Oncogene, 24, 1188-1202. http://dx.doi.org/10.1038/sj.onc.1208276

[25] Li, W., et al. (2011) Molecular Mechanism of Silymarin-Induced Apoptosis in a Highly Metastatic Lung Cancer Cell 
Line Anip973. Cancer Biotherapy and Radiopharmaceuticals, 26, 317-324. http://dx.doi.org/10.1089/cbr.2010.0892

[26] Gu, M., Singh, R.P., Dhanalakshmi, S., Agarwal, C. and Agarwal, R. (2007) Silibinin Inhibits Inflammatory and Angiogenic Attributes in Photocarcinogenesis in SKH-1 Hairless Mice. Cancer Research, 67, 3483-3491. http://dx.doi.org/10.1158/0008-5472.CAN-06-3955

[27] Rajamanickam, S., Velmurugan, B., Kaur, M., Singh, R.P. and Agarwal, R. (2010) Chemoprevention of Intestinal Tumorigenesis in APCmin/+ Mice by Silibinin. Cancer Research, 70, 2368-2378. http://dx.doi.org/10.1158/0008-5472.CAN-09-3249

[28] Kim, S., et al. (2011) Silibinin Suppresses EGFR Ligand-Induced CD44 Expression through Inhibition of EGFR Activity in Breast Cancer Cells. Anticancer Research, 31, 3767-3773.

[29] Provinciali, M., et al. (2007) Effect of the Silybin-Phosphatidylcholine Complex (IdB 1016) on the Development of Mammary Tumors in HER-2/Neu Transgenic Mice. Cancer Research, 67, 2022-2029.

http://dx.doi.org/10.1158/0008-5472.CAN-06-2601 
Scientific Research Publishing (SCIRP) is one of the largest Open Access journal publishers. It is currently publishing more than 200 open access, online, peer-reviewed journals covering a wide range of academic disciplines. SCIRP serves the worldwide academic communities and contributes to the progress and application of science with its publication.

Other selected journals from SCIRP are listed as below. Submit your manuscript to us via either submit@scirp.org or Online Submission Portal.
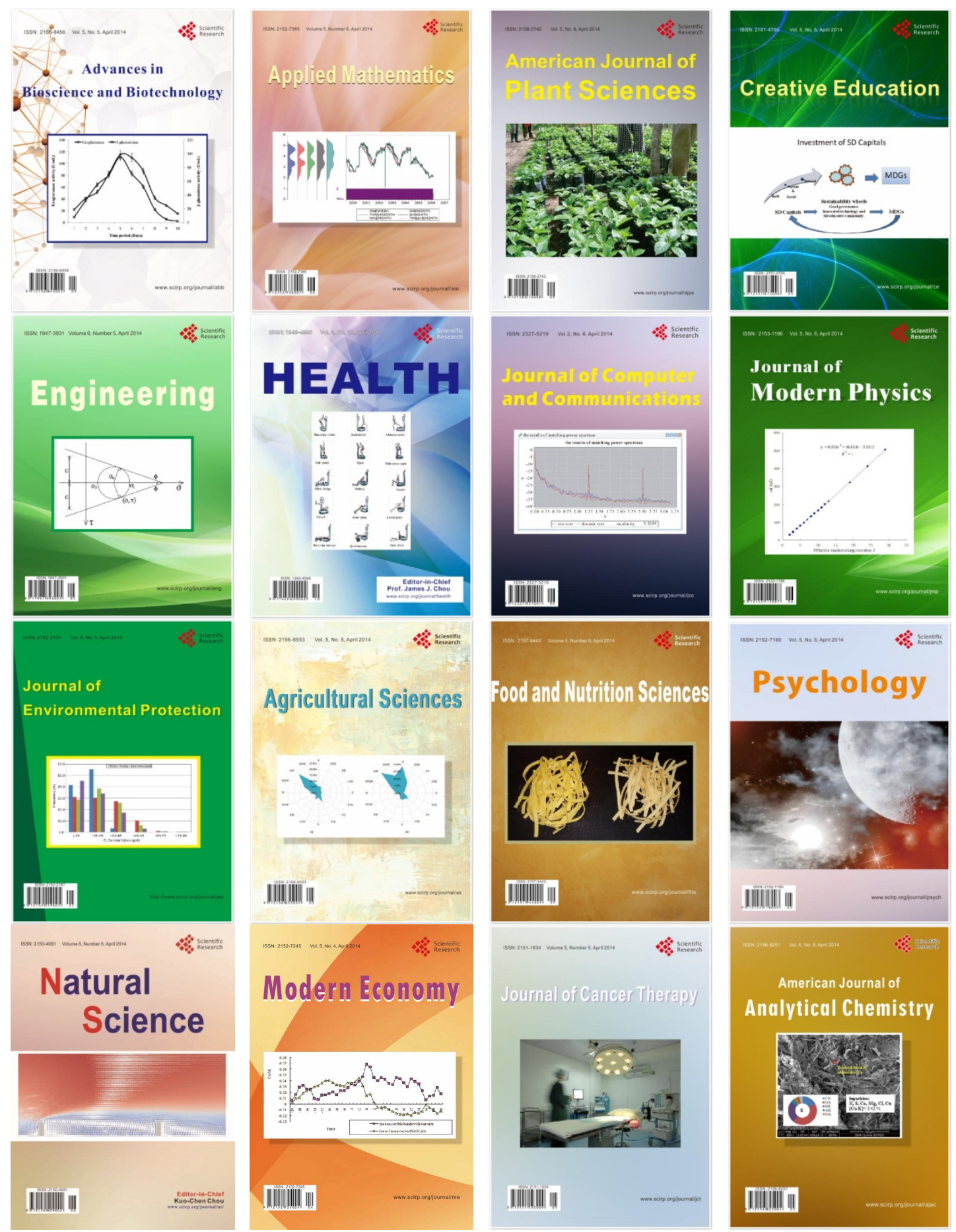